\title{
COLD AGGLUTININS. III. OBSERVATIONS ON CERTAIN SERO- LOGICAL AND PHYSICAL FEATURES OF COLD AGGLUTININS IN CASES OF PRIMARY ATYPICAL PNEUMONIA AND OF HEMOLYTIC ANEMIA
}

\author{
By MAXWELl FINLAND, OSLER L. PETERSON, AND MILDRED W. BARNES \\ WITH THE TECH NICAL ASSISTANCE OF MURIEL B. STONE \\ (From the Thorndike Memorial Laboratory, Second and Fourth Medical Services (Harvard), \\ Boston City Hospital, and the Department of Medicine, Harvard Medical School, Boston)
}

(Received for publication September 22, 1944)

Some of the properties of cold agglutinins in certain human sera have been listed in a recent review (1). The knowledge concerning these properties is based on studies of the phenomenon by various methods in serum or plasma from isolated cases of a large variety of conditions. With respect to the cold agglutinins in cases of primary atypical pneumonia, limited studies of certain aspects were reported in 1918 (2) in one case of atypical bronchopneumonia, in 1938 (3) in a similar case, and recently (4) in a few cases which more closely resemble those of primary atypical pneumonia of unknown etiology with which we have been concerned in the previous papers of this series.

In the course of serological studies of cases of atypical pneumonia beginning in the fall of 1942, a number of observations were made on certain features of the cold agglutinin reaction and on the methods used for demonstrating and titrating these agglutinins. Circumstances did not permit extensive and complete studies of all the aspects of this reaction which were contemplated. A number of the observations that were made are of sufficient interest, however, to warrant a presentation of the results at this time, even though some of them are only of a preliminary nature. The investigations which are reported in this paper deal with two broad categories: (1) some serological properties of the cold agglutinins, particularly their relation to the human group isoagglutinins and to cold agglutinins for erythrocytes of other animals, and (2) certain physical properties of the cold agglutinins. Data concerning certain features of the technique are presented in the paper which follows.

\section{MATERIALS AND METHODS}

Sera. The sera used in the present study were obtained from 3 types of individuals: (1) a number of pa- tients with primary atypical pneumonia that were included in the previous study (5); (2) patients with hemolytic anemia associated with cold agglutinins but without atypical pneumonia (these cases have also been referred to in the previous studies (6)) ; and (3) patients and members of the hospital staff who were free of respiratory disease and of blood dyscrasia. Venous blood was drawn and cell-free serum was obtained by centrifugation after the clotted blood had been warmed at $37^{\circ} \mathrm{C}$. for at least an hour. Some of the sera had been stored for various periods up to 6 months before the studies were made.

Erythrocytes. Blood was obtained from normal human donors by venepuncture and from animals either by cardiac or venous puncture with either a citrate or oxalate anticoagulant. The blood cells were washed 3 times in a large volume of physiological saline and then resuspended in saline.

The technique of the cold agglutination tests was the same as that employed in the previous studies of this series. Deviations from this method will be mentioned specifically along with other details of methods used in each of the experiments.

\section{COMPARISON OF TITERS IN SERUM AND PLASMA}

On a number of occasions, clotted and oxalated samples of blood were obtained at the same time in cases of atypical pneumonia and hemolytic anemia. Titrations of the cold agglutinins were carried out simultaneously on the serum obtained from the clotted blood and on the plasma removed from the corresponding sample of oxalated blood. Identical titers were obtained in every instance. Almost all of the tests to be reported in this paper were carried out on sera removed from clotted blood.

RELATION OF COLD AGGUTININS TO THE BLOOD GROUP SPECIFIC ISOAGGLUTININS

In carrying out the tests for cold agglutinins, group $O$ cells were used routinely in order to avoid agglutination resulting from the group specific agglutinins. In a number of the previous 
TABLE I

Effect of absorption of isohemagglutinins (with Group $A B$ erythrocytes) on the cold agglutination of erythrocytes of all 4 major blood groups

\begin{tabular}{|c|c|c|c|c|c|c|c|c|c|c|c|c|c|}
\hline \multirow{4}{*}{ Serum } & \multirow{4}{*}{$\begin{array}{c}\text { Blood } \\
\text { group } \\
\text { of } \\
\text { patient }\end{array}$} & Unab & orbed & \multicolumn{10}{|c|}{ After absorption with equal volume of washed and packed $\mathrm{AB}$ cells at $37^{\circ} \mathrm{C}$. } \\
\hline & & \multirow{2}{*}{\multicolumn{2}{|c|}{$\begin{array}{l}\text { Microscopic } \\
\text { agglutination }\end{array}$}} & \multirow{2}{*}{\multicolumn{2}{|c|}{$\begin{array}{c}\text { Microscopic } \\
\text { agglutination }\end{array}$}} & \multicolumn{8}{|c|}{ Macroscopic agglutination } \\
\hline & & & & & & \multicolumn{2}{|c|}{$\mathbf{A B}$} & \multicolumn{2}{|c|}{$\mathbf{A}$} & \multicolumn{2}{|c|}{ B } & \multicolumn{2}{|l|}{$0 *$} \\
\hline & & $\mathbf{A}$ & B & A & B & $4^{\circ}$ & $37^{\circ}$ & $4^{\circ}$ & $37^{\circ}$ & $4^{\circ}$ & $37^{\circ}$ & $4^{\circ}$ & $37^{\circ}$ \\
\hline $\begin{array}{l}1 \\
2 \\
3 \\
4 \\
5 \\
6 \\
7 \\
8 \\
9\end{array}$ & $\begin{array}{c}\text { AB } \\
\text { O } \\
\text { A } \\
\text { O } \\
\text { B } \\
\text { A } \\
\text { A } \\
\text { O } \\
\text { O }\end{array}$ & $\begin{array}{c}0 \\
++ \\
0 \\
+++ \\
++ \\
0 \\
0 \\
+++ \\
++\end{array}$ & $\begin{array}{c}0 \\
++ \\
++ \\
+++ \\
0 \\
++ \\
+++ \\
+++ \\
++\end{array}$ & $\begin{array}{l}\mathbf{0} \\
0 \\
0 \\
0 \\
0 \\
0 \\
0 \\
0 \\
0\end{array}$ & $\begin{array}{l}0 \\
0 \\
0 \\
0 \\
0 \\
0 \\
0 \\
0 \\
0\end{array}$ & $\begin{array}{c}32(8) \\
32(4) \\
256(16) \\
1024(64) \\
1024(64) \\
512(64) \\
512(64) \\
256(32) \\
512(64)\end{array}$ & $\begin{array}{l}0 \\
0 \\
0 \\
0 \\
0 \\
0 \\
0 \\
0 \\
0\end{array}$ & $\begin{array}{l}32(4) \\
16(8) \\
128(8) \\
512(32) \\
512(16) \\
128(16) \\
256(16) \\
128(8) \\
512(64)\end{array}$ & $\begin{array}{l}0 \\
0 \\
0 \\
0 \\
0 \\
0 \\
0 \\
0 \\
0\end{array}$ & $\begin{array}{r}64(4) \\
32(8) \\
256(16) \\
512(64) \\
512(64) \\
256(32) \\
256(64) \\
256(16) \\
512(64)\end{array}$ & $\begin{array}{l}0 \\
8 \\
0 \\
0 \\
0 \\
0 \\
0 \\
0 \\
0\end{array}$ & $\begin{array}{c}128(8) \\
128(16) \\
256(32) \\
2048(128) \\
2048(256) \\
1024(64) \\
512(64) \\
512(32) \\
1024(128)\end{array}$ & $\begin{array}{l}\mathbf{0} \\
\mathbf{0} \\
\mathbf{0} \\
\mathbf{0} \\
\mathbf{0} \\
\mathbf{0} \\
\mathbf{0} \\
0 \\
\mathbf{0}\end{array}$ \\
\hline
\end{tabular}

* Identical titers were obtained before absorption and are shown for the corresponding sera (Nos. 1 to 9) in Table III. The +++ end-point in the macroscopic agglutination is shown in parentheses along side the + or \pm end-points. When not shown, +++ end-point was $\angle 4 . \quad 0=<4$ (the lowest dilution tested). All sera heated to $56^{\circ} \mathrm{C}$. for 30 minutes before this test.

reports concerning cold agglutinins, its indepence of the human blood groups was demonstrated. It was of interest to determine whether the same was true for the cold agglutinins found in cases of primary atypical pneumonia.

Experimental. Nine specimens of serum in which the cold agglutinin titers ranged from 128 to 2048 were used in this experiment. These sera were obtained from 9 different cases of atypical pneumonia. In order to avoid hemolysis, the sera were heated at $56^{\circ} \mathrm{C}$. for 30 minutes before the tests were carried out. It was found on repeated tests that this amount of heating does not materially affect the cold agglutinin titers. In order to remove the group specific isoagglutinins, group $A B$ cells which had been washed 3 times in saline were used for absorption. The sera were added to equal volumes of the washed and packed $A B$ cells, mixed thoroughly, and incubated at $37^{\circ} \mathrm{C}$. for 2 hours with frequent mixing during this period. At the end of this time, the serum was removed after centrifugation and tests for cold agglutinins were carried out with the cells of each of the 4 major blood groups. In the readings, +++ represents a few large tight clumps; + and \pm represent the least amounts of definite agglutination readily visible with the naked eye and with the aid of a lens of $3 \times$ magnification, respectively. The titers are given as the reciprocal of the final dilution of serum.

The results are shown in Table I. All of the group specific isohemagglutinins had been removed as shown by the results of the microscopic tests which were carried out with the undiluted sera and suspensions of group $A$ and $B$ cells.
Only minor differences were noted in the titers of cold agglutinins obtained with the group $\mathrm{O}$ cells and with the cells of the other major blood groups. This was true also for the strong $(+++)$ agglutination which was likewise unaffected. The observed differences are no more than those which are to be expected from cells of different donors; as will be shown later. Furthermore, the titer of cold agglutinins for the group $\mathrm{O}$ cells was totally unaffected by the absorption at $37^{\circ} \mathrm{C}$.

\section{RELATION OF COLD ISO- AND AUTOHEM AGGLUTININS}

A systematic study of this phase was not carried out. During the early part of these investigations, a few specimens of serum and plasma having moderate to high titers were tested simultaneously with autologous cells as well as with group $\mathrm{O}$ cells from another donor. Patients of both group $\mathrm{O}$ and of other blood groups were included. The cold agglutinin titers were usually found to be identical or showed a 2 -fold difference in favor of either type of cells. Similar results were obtained in tests of a few bloods from cases of atypical pneumonia reported by others (4).

Since most of the previous workers had made similar observations with respect to cold agglutinins, these studies were not pursued further, it being assumed that these findings were uni- 
formly true. There were 2 cases, however, in which cold autoagglutinins were probably present in moderate or high titers but were not demonstrated at all by the routine tests which employ group $\mathrm{O}$ cells of another donor. The cold agglutination was noted in each of these cases in the course of collecting and handling samples of blood for other purposes and in carrying out red blood counts at room temperature. Cold agglutination was noted in the chilled oxalated blood and at room temperature and this was readily dispersed on heating. Sera obtained at the same time and other specimens obtained both earlier and later and tested with group $\mathrm{O}$ cells were negative for cold agglutinins in both cases. Unfortunately, quantitative studies of the autoagglutination were not done. It would be of interest to know how frequently this phenomenon occurs. Another worker (7) noted some differences between the cold auto- and cold hetero-agglutinin in the blood of a case of syphilitic cirrhosis of the liver.

\section{COLD AGGLUTININS FOR ERYTHROCYTES OF VARIOUS ANIMALS}

To determine the species specificity of the cold agglutinins, tests were done simultaneously with human $O$ cells and with erythrocytes from 9 animal species. The results of such tests in 10 sera without cold isohemagglutinins and in 12 which had them in moderate or high titers are shown in Table II.

All of the animal erythrocytes were agglutinated in the cold to varying titers in the different sera. Rabbit, dog, cat, and rat cells were agglutinated in all of them, guinea pig, sheep, and horse cells in almost all, and hen and monkey cells in more than half of the sera. The highest titers were obtained with the rabbit cells. Dispersal of the cold agglutinated cells at $37^{\circ} \mathrm{C}$. also occurred irregularly, more of the agglutination persisting with rabbit than with other cells. With most of the cells, there was no striking difference in the titers obtained in sera with or without cold isohemagglutinins. Agglutination of monkey cells in the

TABLE II

Cold agglutinins for animal erythrocytes in normal human sera and in sera which have cold agglutinins for human " $O$ " cells

\begin{tabular}{|c|c|c|c|c|c|c|c|c|c|c|c|c|c|c|c|c|c|c|c|c|}
\hline \multirow{2}{*}{ Serum } & \multicolumn{2}{|c|}{ Human "O" } & \multicolumn{2}{|c|}{ Horse } & \multicolumn{2}{|c|}{ Rabbit } & \multicolumn{2}{|c|}{ Guinea pig } & \multicolumn{2}{|c|}{ Sheep } & \multicolumn{2}{|c|}{ Dog * } & \multicolumn{2}{|c|}{ Cat } & \multicolumn{2}{|c|}{ Rat } & \multicolumn{2}{|c|}{ Hen } & \multicolumn{2}{|c|}{ Monkey } \\
\hline & $4^{\circ} \mathrm{C}$ & $37^{\circ} \mathrm{C}$ & $4^{\circ} \mathrm{C}$ & $37^{\circ} \mathrm{C}$. & $4^{\circ} \mathrm{C}$. & $37^{\circ} \mathrm{C}$. & $4^{\circ} \mathrm{C}$. & $37^{\circ} \mathrm{C}$. & $4^{\circ} \mathrm{C}$. & $37^{\circ} \mathrm{C}$. & $4^{\circ} \mathrm{C}$ & $37^{\circ} \mathrm{C}$ & $4^{\circ} \mathrm{C}$ & $37^{\circ} \mathrm{C}$. & $4^{\circ} \mathrm{C}$. & $37^{\circ} \mathrm{C}$. & $4^{\circ} \mathrm{C}$ & $37^{\circ} \mathrm{C}$. & $4^{\circ} \mathrm{C}$. & $37^{\circ} \mathrm{C}$. \\
\hline $\begin{array}{r}1 \\
2 \\
3 \\
4 \\
5 \\
6 \\
7 \\
8 \\
9 \\
10\end{array}$ & $\begin{array}{l}0 \\
0 \\
0 \\
0 \\
0 \\
0 \\
0 \\
0 \\
0 \\
0\end{array}$ & $\begin{array}{l}0 \\
0 \\
0 \\
0 \\
0 \\
0 \\
0 \\
0 \\
0 \\
0\end{array}$ & $\begin{array}{r}20 \\
40 \\
160 \\
80 \\
10 \\
20 \\
20 \\
40 \\
0 \\
80\end{array}$ & $\begin{array}{r}0 \\
0 \\
40 \\
10 \\
0 \\
0 \\
0 \\
0 \\
0 \\
0\end{array}$ & $\begin{array}{r}80 \\
320 \\
320 \\
80 \\
40 \\
160 \\
160 \\
320 \\
80 \\
320\end{array}$ & $\begin{array}{l}10 \\
40 \\
40 \\
10 \\
10 \\
10 \\
10 \\
10 \\
20 \\
20\end{array}$ & $\begin{array}{r}20 \\
20 \\
40 \\
0 \\
40 \\
40 \\
40 \\
80 \\
40 \\
40\end{array}$ & $\begin{array}{l}0 \\
0 \\
0 \\
0 \\
0 \\
0 \\
0 \\
0 \\
0 \\
0\end{array}$ & $\begin{array}{r}20 \\
80 \\
40 \\
0 \\
10 \\
10 \\
20 \\
20 \\
10 \\
0\end{array}$ & $\begin{array}{l}0 \\
0 \\
0 \\
0 \\
0 \\
0 \\
0 \\
0 \\
0 \\
0\end{array}$ & $\begin{array}{r}20 \\
80 \\
80 \\
40 \\
80 \\
40 \\
80 \\
160 \\
40 \\
40\end{array}$ & $\begin{array}{r}0 \\
0 \\
40 \\
0 \\
0 \\
0 \\
10 \\
10 \\
0 \\
0\end{array}$ & $\begin{array}{l}20 \\
80 \\
80 \\
20 \\
10 \\
40 \\
40 \\
40 \\
10 \\
20\end{array}$ & $\begin{array}{r}0 \\
10 \\
10 \\
0 \\
0 \\
0 \\
0 \\
0 \\
0 \\
0\end{array}$ & $\begin{array}{r}80 \\
40 \\
80 \\
40 \\
80 \\
40 \\
160 \\
160 \\
80 \\
20\end{array}$ & $\begin{array}{r}0 \\
0 \\
10 \\
0 \\
0 \\
0 \\
10 \\
10 \\
0 \\
0\end{array}$ & $\begin{array}{r}0 \\
10 \\
0 \\
0 \\
0 \\
0 \\
0 \\
0 \\
0 \\
0\end{array}$ & $\begin{array}{l}0 \\
0 \\
0 \\
0 \\
0 \\
0 \\
0 \\
0 \\
0 \\
0\end{array}$ & $\begin{array}{r}0 \\
0 \\
20 \\
10 \\
20 \\
10 \\
40 \\
20 \\
10 \\
0\end{array}$ & $\begin{array}{r}0 \\
0 \\
0 \\
0 \\
20 \\
0 \\
0 \\
0 \\
0 \\
0\end{array}$ \\
\hline $\begin{array}{l}11 \\
12 \\
13 \\
14 \\
15 \\
16 \\
17 \\
18 \\
19 \\
20\end{array}$ & $\begin{array}{r}128 \\
128 \\
256 \\
2048 \\
2048 \\
1024 \\
512 \\
512 \\
1024 \\
1024\end{array}$ & $\begin{array}{l}0 \\
0 \\
0 \\
0 \\
0 \\
0 \\
0 \\
0 \\
0 \\
0\end{array}$ & $\begin{array}{r}0 \\
4 \\
32 \\
128 \\
32 \\
64 \\
32 \\
128 \\
64 \\
32\end{array}$ & $\begin{array}{r}0 \\
4 \\
8 \\
16 \\
0 \\
0 \\
0 \\
4 \\
16 \\
16\end{array}$ & $\begin{array}{l}256 \\
512 \\
128 \\
256 \\
256 \\
128 \\
128 \\
128 \\
128 \\
128\end{array}$ & $\begin{array}{l}32 \\
64 \\
16 \\
16 \\
32 \\
16 \\
16 \\
16 \\
16 \\
64\end{array}$ & $\begin{array}{r}32 \\
4 \\
64 \\
128 \\
64 \\
128 \\
128 \\
128 \\
128 \\
64\end{array}$ & $\begin{array}{r}0 \\
0 \\
4 \\
32 \\
0 \\
0 \\
4 \\
0 \\
4 \\
4\end{array}$ & $\begin{array}{r}8 \\
4 \\
32 \\
32 \\
64 \\
32 \\
16 \\
32 \\
64 \\
64\end{array}$ & $\begin{array}{l}0 \\
0 \\
0 \\
0 \\
0 \\
0 \\
0 \\
0 \\
0 \\
0\end{array}$ & $\begin{array}{r}16 \\
64 \\
32 \\
32 \\
4 \\
64 \\
32 \\
128 \\
16 \\
128\end{array}$ & $\begin{array}{r}0 \\
0 \\
0 \\
0 \\
0 \\
0 \\
4 \\
0 \\
0 \\
32\end{array}$ & $\begin{array}{r}16 \\
4 \\
32 \\
32 \\
0 \\
16 \\
32 \\
16 \\
16 \\
64\end{array}$ & $\begin{array}{r}8 \\
0 \\
4 \\
16 \\
0 \\
0 \\
4 \\
0 \\
4 \\
8\end{array}$ & $\begin{array}{r}32 \\
128 \\
128 \\
64 \\
8 \\
64 \\
64 \\
128 \\
32 \\
128\end{array}$ & $\begin{array}{r}8 \\
16 \\
16 \\
4 \\
0 \\
4 \\
8 \\
4 \\
8 \\
16\end{array}$ & $\begin{array}{r}16 \\
8 \\
82 \\
0 \\
0 \\
16 \\
32\end{array}$ & $\begin{array}{l}4 \\
\\
0 \\
0 \\
0 \\
0 \\
\\
0 \\
0\end{array}$ & $\begin{array}{r}32 \\
128 \\
32 \\
256 \\
512 \\
128 \\
32\end{array}$ & $\begin{array}{r}0 \\
4 \\
4 \\
4 \\
16 \\
\\
8 \\
0\end{array}$ \\
\hline $\begin{array}{l}21 \\
22\end{array}$ & $\begin{array}{r}320 \\
2560\end{array}$ & $\begin{array}{c}0 \\
10\end{array}$ & $\begin{array}{r}0 \\
80\end{array}$ & $\begin{array}{r}0 \\
20\end{array}$ & $\begin{array}{r}320 \\
1280\end{array}$ & $\begin{array}{r}40 \\
160\end{array}$ & $\begin{array}{r}10 \\
320\end{array}$ & $\begin{array}{l}0 \\
0\end{array}$ & $\begin{array}{r}10 \\
320\end{array}$ & $\begin{array}{l}0 \\
0\end{array}$ & $\begin{array}{r}80 \\
160\end{array}$ & $\begin{array}{l}10 \\
80\end{array}$ & $\begin{array}{r}10 \\
160\end{array}$ & $\begin{array}{r}0 \\
40\end{array}$ & $\begin{array}{l}160 \\
320\end{array}$ & $\begin{array}{l}40 \\
80\end{array}$ & $\begin{array}{l}0 \\
0\end{array}$ & $\begin{array}{l}\mathbf{0} \\
\mathbf{0}\end{array}$ & $\begin{array}{r}160 \\
1280\end{array}$ & $\begin{array}{r}160 \\
80\end{array}$ \\
\hline
\end{tabular}

* Slight to moderate hemolysis in the lower dilutions in all sera.

The sera were all heated at $56^{\circ} \mathrm{C}$. for 30 minutes. Lowest serum dilution tested was $1: 4$ in sera 11 to 20 inclusive and $1: 10$ in all others. $0=$ negative in the lowest dilution tested, end-point + . Sera 1 to 10 are from normals, 11 to 20 are from convalescent cases of atypical pneumonia, and 21 and 22 from cases of acute hemolytic anemia without pneumonia. 
cold occurred more regularly and in higher titers in the sera having cold isoagglutinins and the same was true to less extent with sheep and hen cells. Reversal at $37^{\circ} \mathrm{C}$., however, was incomplete with the monkey cells and occurred regularly with the sheep and hen cells.

Serial specimens of serum from several cases of atypical pneumonia were tested at the same time with human and monkey cells. The results in 4 cases are shown in Table III. There was some correlation but no strict parallelism between the cold agglutinin titers with the 2 kinds of cells and considerable agglutination of the monkey cells persisted at $37^{\circ} \mathrm{C}$. Similar tests were done with human and sheep cells in serial samples from 5 cases. There was no parallel rise of sheep cell agglutination in 2 of these cases while each of the other 3 showed a 4 -fold rise in titer to a maximum of 16 or 32 with complete reversal at $37^{\circ} \mathrm{C}$.

An analysis of the cold agglutinins was made only in a preliminary manner by testing the effect of absorption with human $\mathrm{O}$, rabbit, and guinea pig cells in the cold on the titer of cold agglutinins for these and for monkey cells.

Method. Serum in a dilution of $1: 10$, was mixed with equal volumes of 5 per cent suspensions of cells in saline. The mixture was then kept in an ice bath for 2 hours. At the end of this time, the supernatant fluid was removed after centrifugation in the cold. In order to avoid further dilution, the second and third absorptions were carried out by adding the supernatant fluid to the packed sediment of an equal volume of 5 per cent cells after the saline had been removed. The final absorption was carried out by overnight storage in a refrigerator. The clear supernatant fluid was then used for the cold agglutination tests. The lowest final dilution of absorbed serum, therefore, was 1:20 after the suspensions of the test cells were added.

The results are shown in Table IV. They indicate that rabbit cells contain the broadest cold agglutinating antigen. Absorption with these cells removed the largest amount of cold agglutinin for the human, guinea pig, and monkey cells. Absorption with the human and guinea pig cells, on the other hand, had only slight effect on the titer of cold agglutinins for the heterologous cells.

Other investigators (4) have tested a saline solution of the autoagglutinins of 6 sera from cases of atypical pneumonia with human $\mathrm{O}$ and
TABLE III

Results of tests for cold agglutinins carried out with human Group " $O$ " and monkey erythrocytes in 14 sera from 4 cases of atypical preumonia

\begin{tabular}{|c|c|c|c|c|c|}
\hline \multirow{2}{*}{$\begin{array}{l}\text { Case } \\
\text { No. }\end{array}$} & \multirow{2}{*}{$\begin{array}{l}\text { Day of } \\
\text { disease }\end{array}$} & \multicolumn{2}{|c|}{ Human "O" } & \multicolumn{2}{|c|}{ Rhesus - } \\
\hline & & $4^{\circ}$ & $37^{\circ}$ & $4^{\circ}$ & $37^{\circ}$ \\
\hline 28 & $\begin{array}{l}10 \\
15 \\
27\end{array}$ & $\begin{array}{r}20 \\
1280 \\
160\end{array}$ & $\begin{array}{l}<10 \\
<10 \\
<10\end{array}$ & $\begin{array}{r}10 \\
320 \\
160\end{array}$ & $\begin{array}{r}<10 \\
20 \\
80\end{array}$ \\
\hline 32 & $\begin{array}{r}6 \\
14 \\
19 \\
30\end{array}$ & $\begin{array}{l}<10 \\
<10 \\
320 \\
40\end{array}$ & $\begin{array}{l}<10 \\
<10 \\
<10 \\
<10\end{array}$ & $\begin{array}{r}20 \\
80 \\
160 \\
80\end{array}$ & $\begin{array}{l}10 \\
40 \\
20 \\
40\end{array}$ \\
\hline 33 & $\begin{array}{l}13 \\
14 \\
25\end{array}$ & $\begin{array}{l}320 \\
320 \\
320\end{array}$ & $\begin{array}{l}<10 \\
<10 \\
<10\end{array}$ & $\begin{array}{r}160 \\
40 \\
80\end{array}$ & $\begin{array}{l}20 \\
40 \\
20\end{array}$ \\
\hline 46 & $\begin{array}{l}10 \\
11 \\
17 \\
31\end{array}$ & $\begin{array}{r}<10 \\
20 \\
2560 \\
160\end{array}$ & $\begin{array}{l}<10 \\
<10 \\
<10 \\
<10\end{array}$ & $\begin{array}{l}40 \\
40 \\
80 \\
40\end{array}$ & $\begin{array}{l}20 \\
20 \\
20 \\
20\end{array}$ \\
\hline
\end{tabular}

+ end-points are given.

$\mathrm{AB}$ cells and with rabbit, guinea pig, sheep, horse, mouse, and ox cells. In those studies, the titer of cold agglutinins with rabbit cells were essentially the same as with human cells. Guinea pig and pig cells were agglutinated in low titer; horse and ox cells were not agglutinated at all; and only 2 sera were agglutinated in low titer with sheep or mouse cells. In a second experiment, the same authors tested 5 sera with human $\mathrm{O}$, rabbit, mouse, guinea pig, horse, and sheep cells, before and after absorption with autologous cells. In that experiment, moderate titers of agglutinins were obtained with all cells and the highest titers were obtained with rabbit cells. The agglutinins for the animal cells were not removed by absorption of the sera with the autologous cells.

\section{RELATION OF COLD AGGLUTININS TO HEMOLYSINS}

The reversible cold hemagglutinin for human $\mathrm{O}$ cells was shown to be completely independent of any hemolysin. Several sera which had high titers of cold agglutinins were tested both in the fresh state and after heating at $56^{\circ} \mathrm{C}$. for 30 minutes and adding fresh guinea pig serum. No hemolysis occurred with the human $\mathrm{O}$ cells, either in the cold or after incubation at $37^{\circ} \mathrm{C}$. for 2 hours, in sera from atypical pneumonias or hemolytic anemias. 
TABLE IV

Cold agglutinins: Effect of absorption at $4^{\circ} C$. with human " $O$ ", rabbit, and guinea pig erythrocytes

\begin{tabular}{|c|c|c|c|c|c|c|c|c|c|}
\hline \multirow{3}{*}{$\begin{array}{l}\text { Number } \\
\text { and } \\
\text { diagnosis }\end{array}$} & \multirow{3}{*}{$\begin{array}{l}\text { Erythrocytes } \\
\text { used in } \\
\text { adsorptions }\end{array}$} & \multicolumn{8}{|c|}{ Titer of agglutinins at $4^{\circ} \mathrm{C}$. } \\
\hline & & \multicolumn{2}{|c|}{ Human "O" } & \multicolumn{2}{|c|}{ Rabbit } & \multicolumn{2}{|c|}{ Guinea pig } & \multicolumn{2}{|c|}{ Monkey } \\
\hline & & +++ & + or \pm & +++ & tor \pm & +++ & + or \pm & +++ & + or \pm \\
\hline H. A. & $\begin{array}{l}\text { None } \\
\text { Human "O" } \\
\text { Rabbit } \\
\text { Guinea pig }\end{array}$ & $\begin{array}{r}80 \\
<20 \\
<20 \\
40\end{array}$ & $\begin{array}{r}1280 \\
<20 \\
40 \\
640\end{array}$ & $\begin{array}{r}640 \\
20 \\
<20 \\
80\end{array}$ & $\begin{array}{r}512 \\
1280 \\
<20 \\
2560\end{array}$ & $\begin{array}{r}80 \\
20 \\
<20 \\
<20\end{array}$ & $\begin{array}{r}1280 \\
320 \\
20 \\
40\end{array}$ & $\begin{array}{r}40 \\
20 \\
<20 \\
<20\end{array}$ & $\begin{array}{r}640 \\
160 \\
40 \\
160\end{array}$ \\
\hline A. $\stackrel{2}{P}$. & $\begin{array}{l}\text { None } \\
\text { Human "O" } \\
\text { Rabbit } \\
\text { Guinea pig }\end{array}$ & $\begin{array}{r}20 \\
<20 \\
<20 \\
<20\end{array}$ & $\begin{array}{r}1280 \\
<20 \\
20 \\
160\end{array}$ & $\begin{array}{r}20 \\
20 \\
<20 \\
40\end{array}$ & $\begin{array}{r}2560 \\
320 \\
<20 \\
1280\end{array}$ & $\begin{array}{l}<20 \\
<20 \\
<20 \\
<20\end{array}$ & $\begin{array}{r}320 \\
80 \\
80 \\
<20\end{array}$ & $\begin{array}{r}40 \\
<20 \\
<20 \\
<20\end{array}$ & $\begin{array}{r}640 \\
160 \\
80 \\
640\end{array}$ \\
\hline A. $\stackrel{3}{P}$. & $\begin{array}{l}\text { None } \\
\text { Human "O" } \\
\text { Rabbit }\end{array}$ & $\begin{array}{r}160 \\
<20 \\
10\end{array}$ & $\begin{array}{r}1280 \\
<20 \\
160\end{array}$ & $\begin{array}{r}80 \\
40 \\
<20\end{array}$ & $\begin{array}{l}2560 \\
1280 \\
<20\end{array}$ & & & & \\
\hline
\end{tabular}

H. A. = hemolytic anemia without pneumonia.

Varying degrees of hemolysis were noted, however, when fresh sera were tested with cells of each of the animal species except those of the monkey. This hemolysis occurred in the sera of normal individuals as well as in those of the patients. The extent of this hemolysis was independent of the titer of cold agglutinins obtained with the same cells, and its intensity varied with the species from which the cells were obtained. It was most marked and occurred in dilutions up to $1: 40$ or $1: 80$ with the cells of the guinea pig, sheep, horse, and dog. It was slightly less marked but occurred quitè regularly with hen cells and it was only slight and occurred irregularly with rat cells. With each of these varieties of cells, all of the hemolysis occurred during storage in the refrigerator. Subsequent incubation at $37^{\circ} \mathrm{C}$. for 2 hours did not increase the extent of the hemolysis appreciably except in an occasional serum.

When the sera were heated at $56^{\circ} \mathrm{C}$. for 30 minutes before the tests, all of the hemolysis was completely abolished except with the dog cells. Slight to moderate hemolysis of dog cells occurred with every serum tested,-those from normals as well as those from the patients,-in the lower dilutions (up to $1: 20$ ). This did not usually interfere with the agglutination which occurred in spite of the partial hemolysis and could be read with ease.

\section{SOME PHYSICAL PROPERTIES OF THE COLD AGGLUTININ}

Unfortunately, circumstances did not permit extensive physical and chemical studies of the sera containing high titers of cold agglutinins or of preparations of solutions of the cold agglutinin eluted from erythrocytes. Electrophoretic and antibody nitrogen studies have been made (9) on the serum of a case of gangrene of the extremities which had a high titer of cold agglutinins. The agglutinins in that instance were shown to be associated with the gamma globulin and a titer of 2560 at $4^{\circ} \mathrm{C}$. was found to be equivalent to 1.473 mgm. of antibody nitrogen. In the course of the present studies, a limited number of observations were made on certain physical properties of the cold agglutinin in its original serum. Among these were the effects of various temperatures, of certain adsorbing agents, and of filtration through various types of filters. Although these studies were not very extensive and were not all adequately controlled, some of the findings are of interest.

\section{EFFECT OF VARIOUS TEMPERATURES}

The thermal range of the cold agglutination reaction has been studied by a number of observers some of whom tested sera from cases of atypical pneumonia. In general, the higher the titer, the more likely is the agglutination to per- 
sist as the temperature is increased above $\mathrm{O}^{\circ} \mathrm{C}$. This finding was confirmed in a number of sera early in the course of the present studies. In sera with low or moderate titers, the agglutination was completely abolished at room temperature (22 to $25^{\circ} \mathrm{C}$.), while those with high titers in the cold often showed considerable agglutination even at 30 to $35^{\circ} \mathrm{C}$. Some of them required incubation up to one-half hour or longer at $37^{\circ} \mathrm{C}$. to produce complete dispersion. This was true for sera of atypical pneumonia cases with or without anemia as well as in cases of hemolytic anemia without pneumonia.

The titer of cold agglutinins was not affected by heating at $56^{\circ} \mathrm{C}$. for one-half hour in any of the sera tested. Temperatures of $62^{\circ} \mathrm{C}$. or higher were necessary in order to reduce the cold agglutinin titers appreciably. At temperatures of $66^{\circ} \mathrm{C}$. or higher, all the cold agglutinins were completely removed from the sera. In similar studies made with the blood of cases of trypanosomiasis, it was shown (8) that the cold agglutinins were unaffected by heating for $20 \mathrm{~min}$ utes at $58^{\circ} \mathrm{C}$. but were completely destroyed at $70^{\circ} \mathrm{C}$.

\section{EFFECT OF CERTAIN ADSORBING AGENTS}

Method. Each of the adsorbents was passed through a copper sieve having a mesh of 100 micra. The $\mathrm{pH}$ of suspensions of these agents in saline ranged between 6.8 and 7.4 and, therefore, no buffers were added in these experiments. Equal volumes of the adsorbent and saline dilutions of serum were mixed thoroughly and incubated in a water bath of $37^{\circ} \mathrm{C}$. for 2 hours with frequent and thorough stirring. The serum dilutions varied from $1: 10$ to $1: 40$, the higher ones being used in sera originally having high titers. After incubation, the mixtures were centrifuged at 2900 r.p.m. The clear supernatant fluid was then removed and tested for cold agglutinins in the usual manner. Sera of patients with hemolytic anemia or atypical pneumonia that had moderate to high titers of cold agglutinins were used in these tests.

The effect of the different adsorbents varied considerably. A list of the agents used and a summary of their effect on the cold agglutinin titers is given in Table V. Casein, silicon dioxide, alundum, and wood charcoal had no discernible effect on the titers in any of the sera that were tested. Bone charcoal, blood charcoal, and norit reduced the titers of most of the sera but left some unaffected. Vegetable charcoal and permutit reduced the titers in all of the sera tested but to a varying extent. Fuller's earth and kaolin removed all of the cold agglutinins completely or nearly so.

\section{EFFECT OF FILTRATION}

The result of the preceding experiment suggested the possibility that filtration through certain types of filters might materially reduce the cold agglutinin titers. A number of tests were carried out with various filters including new as well as previously used ones of some types. Divergent results were obtained with the various filters as shown in Table VI.

Filter paper and fritted glass filters of fine

TABLE $V$

Effect of certain adsorbing agents on the cold agglutinin titers of sera from cases of hemolytic anemia and of primary atypical pneumonia

\begin{tabular}{l|c|c|l}
\hline \multirow{2}{*}{ Adsorbing agent } & \multicolumn{2}{|c|}{ Number of sera } & \\
\cline { 2 - 3 } & H.A. & A.P. & \\
\hline Casein & 3 & 6 & None \\
Silicon dioxide & 3 & 5 & None \\
Alundum & 1 & 3 & None \\
Wood charcoal & 3 & 6 & None \\
Bone charcoal & 2 & 5 & 2 H. A. unaffected, others reduced 4 to 16-fold. \\
Vegetable charcoal & 2 & 5 & All reduced 4 to 32-fold. \\
Blood charcoal & 4 & 5 & 2 A. P. unaffected, others reduced 8-fold or more. \\
Norit & 4 & 5 & 3 (2 A. P. and 1 H. A.) unaffected, others reduced 16-fold or more. \\
Permutit & 3 & 4 & 2 (1 A. P. and 1 H. A.) reduced 4-fold, others reduced 16-fold or more. \\
Fuller's Earth & 4 & 5 & All completely removed or nearly so \\
Kaolin & 4 & 5 & All completely removed or nearly so. \\
\hline
\end{tabular}

H. A. = hemolytic anemia cases; A. P. = cases of primary atypical pneumonia. The original titers of these sera before adsorption ranged from 320 to 5120 . The smallest final dilution tested after adsorption was 20 in most instances; and 40 and 80 in the case of 2 of the sera with the highest original titers. 
TABLE VI

Effect of filtration on cold agglutinin titers

\begin{tabular}{|c|c|c|c|c|c|c|c|c|c|c|c|c|}
\hline \multirow{3}{*}{ Serum } & \multirow{3}{*}{ Diagnosis } & \multirow{3}{*}{$\begin{array}{c}\text { Titer } \\
\text { before } \\
\text { filtration }\end{array}$} & \multicolumn{8}{|c|}{ Titer after filtration } & \multirow{3}{*}{$\begin{array}{c}\text { Fritted } \\
\text { glass }\end{array}$} & \multirow{3}{*}{$\begin{array}{l}\text { Seitz } \\
\text { EK, }\end{array}$} \\
\hline & & & \multirow{2}{*}{$\begin{array}{l}\text { Filter } \\
\text { paper }\end{array}$} & \multicolumn{2}{|c|}{ Mandler } & \multicolumn{5}{|c|}{ Berkefeld filters } & & \\
\hline & & & & Used & New & $\begin{array}{l}\text { "W" } \\
\text { used }\end{array}$ & "W" & $\begin{array}{l}\text { "N" } \\
\text { used }\end{array}$ & $\begin{array}{l}\text { "V" } \\
\text { used }\end{array}$ & $\begin{array}{l}\text { "V" } \\
\text { new }\end{array}$ & & \\
\hline $\begin{array}{r}1 \\
2 \\
3 \\
4 \\
5 \\
6 \\
7 \\
8 \\
9 \\
10 \\
11 \\
12\end{array}$ & $\begin{array}{l}\text { A. P. } \\
\text { H. A. } \\
\text { H. A. } \\
\text { H. A. } \\
\text { A. P. } \\
\text { A. P. } \\
\text { A. P. } \\
\text { A. P. } \\
\text { A. P. } \\
\text { A. P. } \\
\text { A. P. } \\
\text { A. P. }\end{array}$ & $\begin{array}{r}640 \\
640 \\
640 \\
5120 \\
1280 \\
1280 \\
640 \\
160 \\
1280 \\
5120 \\
80 \\
320\end{array}$ & $\begin{array}{l}640 \\
640\end{array}$ & $<20$ & $\begin{array}{r}640 \\
80 \\
320\end{array}$ & $<20$ & $\begin{array}{r}<40 \\
40 \\
<20\end{array}$ & $<20$ & $\begin{array}{r}<20 \\
<160 \\
<160 \\
<20\end{array}$ & $\begin{array}{l}320 \\
320 \\
640 \\
640 \dagger \\
<20\end{array}$ & $\begin{array}{r}1280 \\
640\end{array}$ & $\begin{array}{c}<10 \\
<40 \\
<40 \\
320^{*} \\
640 \\
<20 \\
<10 \\
<10 \\
<160 \\
<160\end{array}$ \\
\hline
\end{tabular}

H. A. = hemolytic anemia without atypical pneumonia.

A. P. = atypical pneumonia. Serum No. 10 was from a case of A. P. after severe hemolytic anemia occurred.

Ten layers of Whatman Nos. 2, 5, 42, and 50 were used in small Seitz filter holder. The Mandler filter was of "average" porosity. The fritted glass was $12 \mathrm{G} 4$ (filter size).

* Titer 640 obtained with this serum when the experiment was repeated.

† Same titer obtained when experiment was repeated.

porosity had no effect. Variable results were obtained with Mandler filters and Berkefeld filters of different porosities but the used ones removed some or all of the agglutinins more often than did the new ones. Seitz filters, on the other hand, removed the agglutinins from 8 of 10 sera tested and materially reduced the titer in 1 of the others. Attempts to elute the agglutinins from the filter pads were not successful.

One of the objects of these experiments was to see whether cold agglutinins in hemolytic anemia could be differentiated from those in atypical pneumonia. These studies failed to accomplish that aim.

\section{EXPERIMENTS WITH PNEUMONIC LUNG AND OTHER TISSUES}

Preliminary experiments were made on the relation of the affected lung from fatal cases of atypical pneumonia to the cold agglutination reaction. In one experiment, suspensions of the diseased lung obtained at autopsy from 6 patients in whom antemortem sera showed moderate titers of cold isohemagglutinins were tested for cold agglutinins. The tissues were incubated at $37^{\circ} \mathrm{C}$. for an hour and then thoroughly ground with alundum after adding 4 volumes of saline. After an additional 30 minutes of incubation, the mix- tures were centrifuged and the supernatant fluids, treated like serum, were tested for cold agglutinins with human $\mathrm{O}$ cells. No agglutination occurred with any of these preparations.

In a second experiment, the effect of such lung preparations on the cold agglutinins of the patients' sera was tested. Antemortem sera from 2 cases were set up for the cold agglutination test in triplicate. One of the sets of tubes containing $0.5 \mathrm{ml}$. each of serial dilutions of serum and equal volumes of 2 per cent suspension of human $\mathrm{O}$ cells was used as a control. To each tube in the second and third sets were added $0.1 \mathrm{ml}$. amounts of a 1:5 and 1:50 dilution, respectively, of the patients' own cleared lung suspension. Agglutination was then read after storage in the ice box over night. In one of these tests, the cold agglutinin titer was reduced from 160 to 10 by the concentrated suspension of lung and to 40 by the $1: 50$ suspension. In the second test, the control titer was only 20 and no agglutination occurred after addition of either of the lung suspensions.

Two other sera from recovered cases were tested in a similar manner with uninvolved and with consolidated portions of lung and with spleen obtained at autopsy from cases of bacterial pneumonia, and also with normal mouse lung. One of these sera had a cold agglutinin titer of 640 
and the titer of that serum after addition of 20 per cent tissue suspensions ranged from 40 to 80 . In the second serum, the original cold agglutinin titer was 160 and the titers of the same serum with 20 per cent tissue extracts added in $0.1 \mathrm{ml}$. amounts was 40 to 80 . In neither case was there any difference between the effect of spleen or of normal or infected lungs.

Hemoglobin solutions and suspensions of red blood cell stroma were used in the same manner as the tissue suspensions. In these experiments, the concentrations of hemoglobin and of red blood cell stroma suspensions were based on the volumes of packed red blood cells, and the concentrations added to the serum-cell mixtures in the cold agglutination tests corresponded to those used in the experiments with other tissues. Neither the hemoglobin solutions nor the suspensions of red cell stroma had any effect whatever on the cold agglutinin titers of the same sera.

These findings suggest the possibility that the affected lung from cases of atypical pneumonia could remove or inhibit the cold agglutinins to a greater extent than the same or other tissues from other sources. Further observations, however, are necessary in order to determine the validity of these findings.

\section{DISCUSSION}

This paper has been devoted to a presentation of a number of observations on the cold agglutinins found in cases of primary atypical pneumonia and of hemolytic anemia. While the results of these studies have some general interest merely as biological observations, the objective of the studies was to define, if possible, the nature of the cold agglutinins in primary atypical pneumonia with the idea of shedding some light on the etiology of this disease. The results of most of these studies revealed no differences between the cold agglutinins in cases of atypical pneumonia and those in the cases of hemolytic anemia without pneumonia. The possibility that the two conditions might be related, however, has some basis. This is suggested by the occurrence of hemolytic anemia, as well as other phenomena such as thrombophlebitis and acrocyanosis, in occasional cases of atypical pneumonia. Cases of these conditions without pneumonia have been found to be associated with autohemagglutination. The relationship, however, may be quite indirect and similar to the finding of heterophile antibodies as a result of a large variety of bacterial infections or following immunizations with bacteria or foreign proteins. The common antigen has not been identified. The present studies indicate quite definitely that the cold agglutinin is not a Forssman antibody though it may be some other type of heterogenetic antibody.

Some of these results, though preliminary in nature, are presented because of their general interest. It is possible that further studies by others who are in a better position to pursue them may yield useful information and shed more light on the now obscure nature of the cold agglutination phenomenon and also on the nature and causes of primary atypical pneumonia and of some of the other conditions associated with cold agglutinins.

\section{SUMMARY AND CONCLUSIONS}

A number of serological and physiological properties of cold agglutinins were studied in sera obtained from a number of cases of primary atypical pneumonia and from 2 cases of hemolytic anemia without pneumonia.

Cold agglutinin titers are the same in serum and plasma obtained from the same blood.

The complete independence of cold agglutinins and blood group isohemagglutinins was confirmed. Absorption of the group-specific agglutinins from sera containing moderate or high titers of cold agglutinins left the latter intact.

While cold autohemagglutination and cold isohemagglutination almost always co-exist, suggestive evidence was obtained in two cases of the possible independence of these two reactions.

Cold agglutinins for the erythrocytes of several animal species were found both in normal sera which lacked cold agglutinins for human $O$ cells and in sera from cases of atypical pneumonia and hemolytic anemia in which cold agglutinins for human $\mathrm{O}$ cells were found in high titer. The erythrocytes of some of these animals were agglutinated more strongly and in higher titer in sera containing high titers of cold agglutinins for human cells than they were in the sera of normal individuals. Rabbit cells showed the strongest 
cold agglutination and, in absorption tests, appeared to have the widest antigenic action. Some rises in titer of cold agglutinins for sheep and monkey cells were observed in a few cases of atypical pneumonia but the reversal of the agglutination with the monkey cells at $37^{\circ} \mathrm{C}$. was irregular and incomplete.

The cold isohemagglutinin was not related to any hemolysin demonstrable in vitro for either human or animal cells.

Cold isohemagglutination is dispersed as the temperature is raised above $5^{\circ} \mathrm{C}$. The thermal range in any given blood depends on the titer and intensity of the cold agglutination reaction in that blood. In most instances, the agglutination is completely dispersed at room temperature (20 to $25^{\circ} \mathrm{C}$.) but in sera of high titer, incubation at $37^{\circ} \mathrm{C}$. for 30 minutes or longer may be required to give complete dispersion.

The cold isohemagglutinins are unaffected by heating at $56^{\circ} \mathrm{C}$. for 30 minutes. Partial destruction of the cold agglutinin occurs at $62^{\circ}$ to $65^{\circ} \mathrm{C}$. and the agglutinins are completely destroyed by heating for 30 minutes at temperatures of $66^{\circ} \mathrm{C}$. or higher.

Certain common adsorbing agents had no effect whatever on the cold isohemagglutinins while others removed them either partially or completely from some or from all of the sera tested.

Filtration through common types of bacterial filters at room temperature may remove some or all of the cold isohemagglutinins. Seitz asbestos filter pads were most active in removing the cold isohemagglutinins.

There was no difference in the behavior of sera from cases of atypical pneumonia and of hemolytic anemia without pneumonia with respect to the effects of heating, of adsorbing agents, or of filtration. The same was true of the agglutination of animal erythrocytes.

Preliminary observations on the effect of various tissues suggest the possibility that the diseased lung of cases of atypical pneumonia may inhibit the cold isohemagglutinin to a greater extent than do tissues from other sources. These studies, however, need further extension and confirmation.

The authors are indebted to Dr. F. H. L. Taylor for helpful advice.

\section{BIBLIOGRAPHY}

1. Stats, D., and Wassermann, L. R., Cold hemagglutination-an interpretive review. Medicine, 1943, 22, 363.

2. Clough, M. C., and Richter, I. C., A study of an autoagglutinin occurring in a human serum. Bull. Johns Hopkins Hosp., 1918, 29, 86.

3. Wheeler, K. M., Gallagher, H. J., and Stuart, C. A., An unusual case of autoagglutination. J. Lab. and Clin. Med., 1939, 24, 1135.

4. Turner, J. C., and Jackson, E. B., Serological specificity of an auto-antibody in atypical pneumonia. Brit. J. Exper. Path., 1943, 24, 121.

5. Finland, M., Peterson, O. L., Allen, H. E., Samper, B. A., and Barnes, M. W., Cold agglutinins. II. Cold isohemagglutinins in primary atypical pneumonia of unknown etiology with a note on the occurrence of hemolytic anemia in these cases. J. Clin. Invest., 1945, 24, 458.

6. Finland, M., Peterson, O. L., Allen, H. E., and Samper, B. A., Cold agglutinins. I. Occurrence of cold isohemagglutinins in various conditions. J. Clin. Invest., 1945, 24, 451.

7. Chen-Pien, $\mathrm{Li}$, Investigation on "cold" or autohemagglutination. J. Immunol., 1926, 11, 297.

8. Yorke, W., Autoagglutination of the red blood cells in trypanosomiasis. Ann. Trop. Med., and Parasitology, 1910, 4, 529.

9. Stats, D., Perlman, E., Bullowa, J. G. M., and Goodkind, R., Electrophoresis and antibody nitrogen determination of a cold hemagglutinin. Proc. Soc. Exper. Biol. and Med., 1943, 53, 188. 